\title{
Soybean Oil: How Good or How Bad in Comparison with Other Dietary Oils in the Context of Colon Cancer
}

\author{
Tatiana Fiche Salles Teixeira, Ana Paula Boroni Moreira, \\ Damiana Diniz Rosa and Maria do Carmo Gouveia Peluzio \\ Universidade Federal de Viçosa \\ Brazil
}

\section{Introduction}

Soybeans (Glycine Max) are one of the oldest crops cultivated around the world, and in Asia soyfoods have been consumed for more than 1000 years. The soybean was popularized because of its high content of protein and good percentage of lipids. World consumption of soybeans in 2008 was over 221 million metric tons, with approximately $50 \%$ of this supply coming from US production, where over 77 million ha are planted annually. Soybeans are desired in the market as a source of protein and oil. Nowadays, soy has a huge economic importance because the beans are very versatile and can be used not only for human and animal nutrition but also for industrial products (Clemente \& Cahoon 2009).

Many beneficial effects of soy components such as soy protein, isoflavones, phytosterols, inositol hexaphosphate and saponins have been suggested, including the beneficial role for inhibition of tumor development in animal models (Hawrylewicz, Zapata et al. 1995). This has stimulated, in only the last 30 years, soybean introduction into western cultures and diets as different sub-products (Golbitz 1995). These products are usually fermented (tempeh, miso, soy sauces, natto, fermented tofu) or non-fermented (fresh soybeans, whole dry soybeans, soy nuts, soy sprouts, whole-fat soy flour, soymilk, tofu, soy protein, soy oil). One of the most used nonfermented subproduct is the soybean oil. The oil represents approximately $20 \%$ of the grain and is influenced by both genotype and environmental factors, and in some countries this is the main sub-product utilized in the diet (Clemente \& Cahoon 2009).

Soybean oil is a representative source of lipids in human nutrition. There are proposed mechanisms that explain lipids involvement in cancer development, especially colorectal cancer (CRC). Thus, comparing soybean oil composition with other oils is a discussion that is relevant in the context of CRC, once this is a public health concern.

\section{Cancer epidemiology}

Cancer is a major public health problem in the United States (US) and in others parts of the world (Jemal, Siegel et al. 2010). According to GLOBOCAN 2008 statistics, CRC is the third 
most incidental type of cancer in men and the second in women worldwide and accounts for $8 \%$ of all cancer deaths, making it the fourth most common cause of death from cancer. Almost $60 \%$ of the cases occur in developed regions (Ferlay, Shin et al. 2010 ).

Changes in the incidence of CRC have been observed worldwide, with a statistically significant increase in its incidence from 1983-87 to 1998-2002. Europe, Slovakia, Slovenia and Czech Republic have shown the largest increase ( $>45 \%$ for men and $25 \%$ for women). In countries of Western Europe (France, Italy, England, Germany and Switzerland) the CRC incidence has remained stable or increased only slightly, except for Spain which presented large increases. In Asia, the largest increases were observed in Japan, Kuwait and Israel, and some areas with large increases in incidence, such as India, Thailand and Kuwait, still maintained relatively low incidence rates. In China, incidence increased by $50 \%$ in Shanghai compared with $10 \%$ in Hong Kong. In contrast, the incidence rates decreased significantly for the US population of both sexes, as well as for Canadian and New Zealand women. In general the increase was largely confined to economically transitioning countries and stabilized in the majority of developed countries, decreasing only in the US. The technology available for CRC screening can influence incidence rates since techniques such as colonoscopy are able to reduce this incidence through the removal of precancerous polyps. In the US, colonoscopy has been the most used screening test, which may be contributing to the decreased incidence rates (Center, Jemal et al. 2009; Murphy, Devesa et al. 2011).

Colorectal cancer is considered a multifactorial disease. The fact that cancer incidence and mortality rates vary dramatically worldwide, and that population migrating from a low to high-incidence country will present approximate rates of the new region, indicate that environmental and lifestyle factors are important determinants in cancer rates (Willett 2001). It is estimated that $25 \%$ of the cases are related to hereditary factors while $75 \%$ are related to other risk factors such as smoking, obesity, sedentarism, aging and dietary habits (Wallace \& Caslake 2001). The adoption of a western lifestyles and behaviors such as high fat diets, physical inactivity and increase in obesity prevalence has been pointed out as one of the environmental factors associated with genetic vulnerability that could explain the increase in CRC incidence rates in economically transitioning countries (Center, Jemal et al. 2009).

Diet is definitely a modifiable exogenous influence on etiology of CRC (Labianca \& Beretta 2010). One of the dietary factors suspected of playing a role on the incidence of CRC is fat intake. The suspicion that fat intake is related to cancer incidence is resultant from the observation that there are large differences in the fat consumption per capita around the world and also differences in cancer rates (Willett 1998), however these data are still controversial. One of the limitations of epidemiological studies is the fact that they do not provide proof of an association between fat and CRC incidence due to measurement error in food frequency questionnaire-based dietary assessment, which can cause attenuation of risk estimations (Flood, Velie et al. 2003). Many animal studies have shown the importance of the type and amount of fat on carcinogenesis (Coleman, Landström et al. 2002; Dwivedi, Natarajan et al. 2005; Boateng, Verghese et al. 2006), while studies assessing human dietary patterns suggest a decreased risk of CRC associated with a higher frequency of low-fat foods (Flood, Rastogi et al. 2008) or a higher risk associated with a western dietary pattern, characterized by greater intakes of red and processed meats, sweets and desserts, high-fat dairy foods, french fries and refined grains (Fung, Hu et al. 2003). Thus, public health campaigns promoting healthier dietary patterns are one of the measures that should be 
taken to help prevent cancer (Jemal, Bray et al. 2011). Thus, understanding how fats, more specifically fatty acids, can play a role in carcinogenesis, must be considered to direct these public health campaigns to prevent increases in cancer incidence.

\section{Production, intake and oils composition}

From an evolutionary perspective, the combination of our ancient genome with the nutritional qualities of recently introduced foods may underlie many chronic diseases of western civilization, including cancer (Cordain \& Eaton 2005). One of the main changes in the human diet refers to the type and quantity of fatty acids and antioxidant content of foods. In the last 20 years, significant changes have occurred in the consumption of lipid sources, with reduction of animal fat intake and increase in the intake of vegetable oils (Simopoulos 2008).

The advent of the oil-seed processing industry significantly raised the total intake of refined vegetable oils. During the period from 1909 to 1999 there was a significant increase in the use of these oils, representing roughly $17.6 \%$ of energy intake in the western diet. This resulted in a direct increase in the level of $\omega-6$ polyunsaturated fatty acids (PUFAs) at the expense of a lowered level of $\omega-3$ PUFA since vegetable oils are inherently richer in the first (Cordain \& Eaton 2005). The utilization of grains in animal diets and oil hydrogenation has also contributed to the increased level of linoleic acid (LA, 18:2, $\omega-6)$ in the diets (Simopoulos 2008).

The major oilseeds supplied and distributed around the world are copra, cottonseed, palm kernel, peanut, rapeseed, soybean and sunflower seed. The soybean, from a commodity viewpoint is number one in terms of production, importation and exportation, while for the production of vegetables oils it is the second seed most used, behind palm oil (Figure 1). Soybean oil is the second most consumed oil, and from 2006 to 2011 its consumption increased by $17.8 \%$. The main countries consuming vegetable oils are China, EU-27, India, US, Indonesia and Brazil (Figure 2), and soybean oil is particularly most consumed in China, US, Brazil, India, EU-27 and Argentina (Figure 3).

The hallmark of the increase in oilseed consumption relates to the changes in the proportion of fatty acids in the diet. The main fatty acids in concern are from $\omega-3$ and $\omega-6$ family. Alpha-linolenic acid (ALA, 18:3 $\omega$-3; found in oils, nuts, seeds), eicosapentaenoic acid (EPA, 20:5 $\omega-3$ ) and docosahexaenoic acid (DHA, 22:6 $\omega-3$ ) are members of $\omega-3$, these last two mainly found in animal sources (such as fish, fish oil), while the most common fatty acids from $\omega-6$ family are LA (mainly vegetable sources) and arachidonic acid (AA, 20:4 $\omega-6$; mainly from animal sources) (Roynette, Calder et al. 2004; Russo 2009). In a typical American diet, $89 \%$ of the PUFA consumed is LA, while $9 \%$ is ALA, being that vegetable oils are the main sources of both. This large difference between $\omega-6$ and $\omega-3$ fatty acids in the western diet is implicated in the increase of the $\omega-6: \omega-3$ ratio, especially when fish and fish oil intake is low. On the other hand, in Europe over the last two decades a $50 \%$ increase in LA intake has been observed (from 10 to $15 \mathrm{~g} /$ day) and a $100 \%$ increase in ALA (from 1 to $1.9 \mathrm{~g} /$ day) (Russo 2009), reducing this ratio. According to Russo (2009), the proportion 1:1 ( $\omega-6: \omega-3)$ presumed to be consumed by ancient civilization has been replaced by 15:1 - 20:1 in some moderns civilizations of western regions (Simopoulos 2008). 


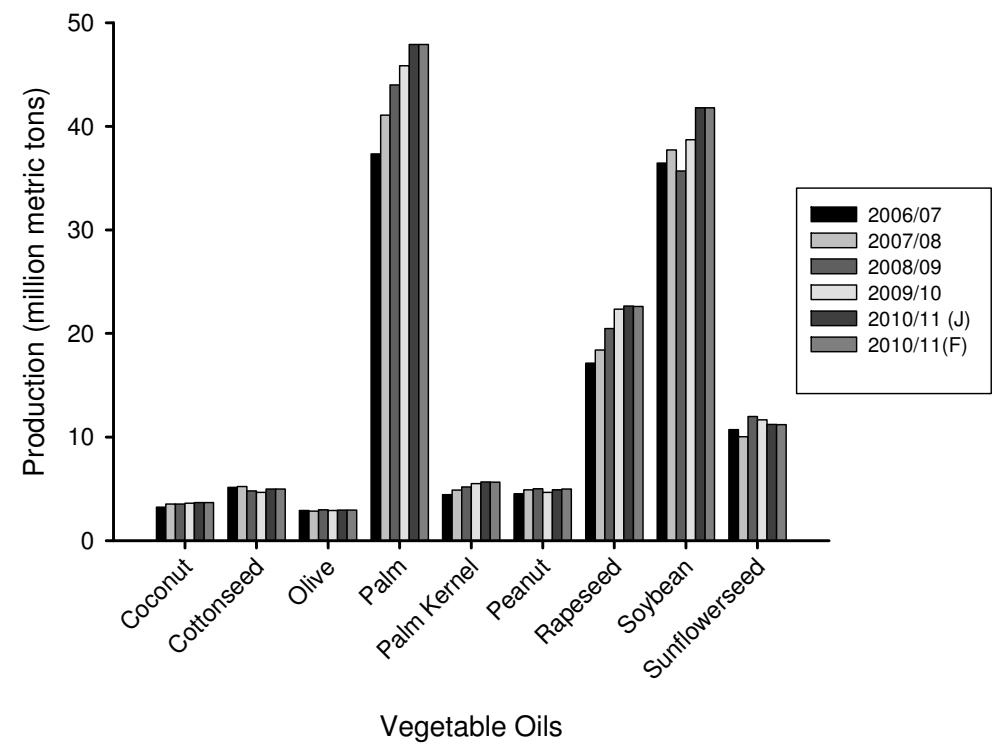

Fig. 1. Major vegetable oils produced (million metric tons) from 2006 to January (J) and February (F) of 2011 (Source: USDA).

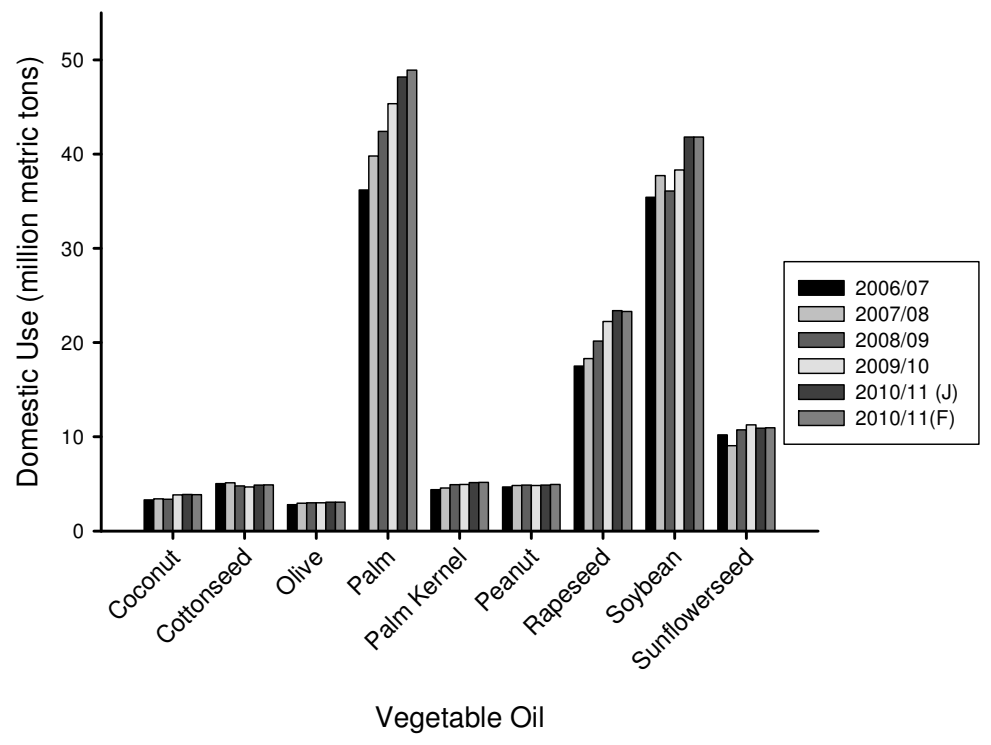

Fig. 2. Domestic consumption of major vegetable oils (million metric tons) from 2006 to January (J) and February (F) of 2011 (Source: USDA). 


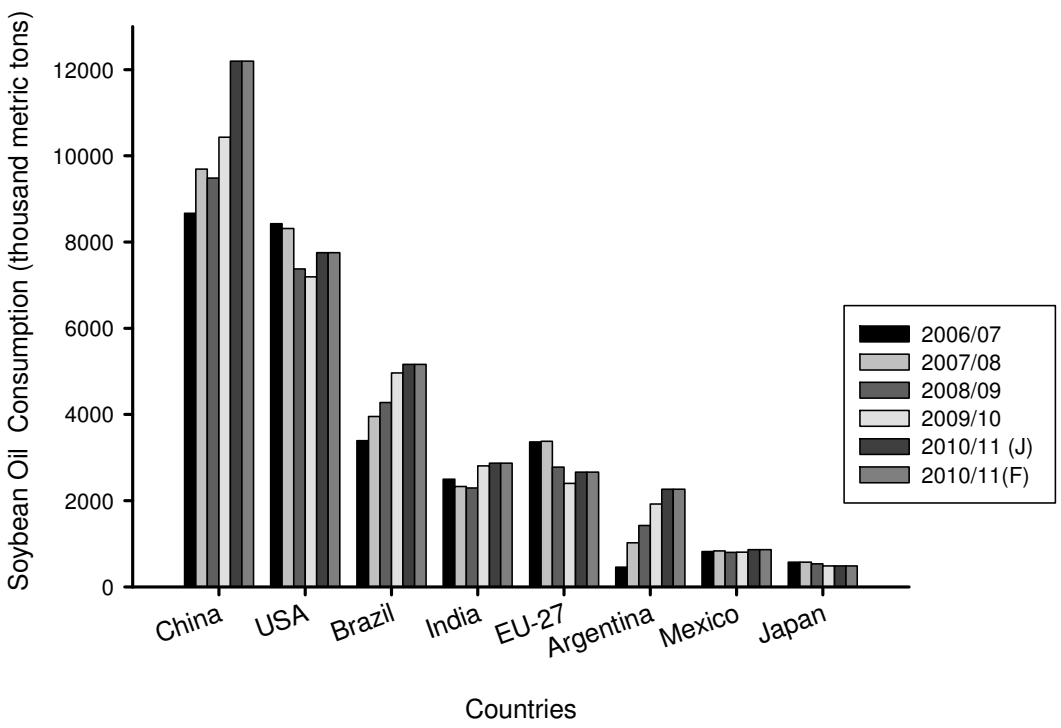

Fig. 3. Domestic consumption of soybean oil (thousand metric tons) from 2006 to January (J) and February (F) of 2011 (Source: USDA).

Considering the economic importance and the high dietary intake of soybean oil, it should be discussed its composition in comparison with other oils of importance in human nutrition (Table 1). The major fatty acid in sunflower, soybean and corn oils is the LA. The canola oil has approximately $21 \%$ of LA, while palm, flaxseed, olive oil have less than $16 \%$, and fish oil less than 3\%. Vegetables oils only present $\omega-3$ in the form of ALA. Flaxseed has a high level of ALA (more than 50\%), while the other oils has less than $7 \%$. The soybean and canola oil have similar quantities of ALA and the highest content after flaxseed, showing levels 7-21 fold higher in comparison to other oils than flaxseed. The palm oil, is together with soybean oil, the most consumed oil, but it should be highlighted that it has 3 to 4 -fold more saturated fatty acids in comparison with other vegetable oils, what may be a disadvantage considering the role of saturated fats on cardiovascular risks. The fish oil, although is from animal source, is included in this table because is the only source of oil directly providing EPA and DHA, which accounts for more than half of its fatty acid composition. Its ALA content is low and soybean oil has 8 times more ALA than fish oil.

\section{Importance of PUFAs in human nutrition}

The effects of oils and fats in human nutrition have been largely discussed in the last decades, emphasizing the reduced intake of saturated and trans fatty acids and the increase in $\omega-3$ intake (Wortman, Miyazaki et al. 2009).

ALA and LA are considered essential because they are not synthesized in the human body due to the lack of enzymes capable of inserting double bonds in the third and sixth carbons counted from the methyl terminal (Roynette, Calder et al. 2004). The LA is converted into AA. In mammals, the essential fatty acids ALA can be converted to EPA and DHA, but the endogenous rate of conversion is unknown. It is believed that this conversion might be low, 
approximately $5-10 \%$ of the ALA is converted to EPA and $2-5 \%$ to DHA in healthy adults (He 2009).

\begin{tabular}{|c|c|c|c|c|c|c|c|c|}
\hline \multirow{2}{*}{$\begin{array}{l}\text { Fatty } \\
\text { Acids }\end{array}$} & \multicolumn{8}{|c|}{ Concentrations $^{a}$} \\
\hline & $\begin{array}{c}\text { Soybean } \\
\text { oil (1) }\end{array}$ & $\begin{array}{l}\text { Corn } \\
\text { oil (2) }\end{array}$ & $\begin{array}{c}\text { Sunflower } \\
\text { oil (2) }\end{array}$ & $\begin{array}{c}\text { Canola } \\
\text { oil (2) }\end{array}$ & $\begin{array}{l}\text { Palm } \\
\left.\text { oil( }^{2}\right)\end{array}$ & $\begin{array}{l}\text { Olive } \\
\text { oil (1) }\end{array}$ & $\begin{array}{c}\text { Flaxseed } \\
\text { oil (1) }\end{array}$ & $\begin{array}{l}\text { Fish } \\
\text { oil (1) }\end{array}$ \\
\hline C14:0 & ND & $\mathrm{ND}$ & 0.07 & 0.06 & 0.79 & ND & ND & 5.86 \\
\hline C15:0 & ND & ND & ND & ND & ND & ND & ND & 0.22 \\
\hline $\mathrm{C} 16: 0$ & 7.75 & 12.12 & 6.10 & 4.59 & 36.77 & 11.30 & 6.45 & 10.76 \\
\hline $\mathrm{C} 17: 0$ & ND & ND & ND & ND & ND & ND & ND & 0.50 \\
\hline C18:0 & 3.01 & 2.18 & 3.42 & 2.21 & 4.61 & 2.96 & 4.35 & 3.60 \\
\hline C20:0 & ND & 0.49 & 0.26 & 0.57 & 0.35 & 0.38 & ND & 0.48 \\
\hline C22:0 & 0.34 & 0.18 & 0.67 & 0.30 & 0.10 & 0.12 & ND & ND \\
\hline C24:0 & ND & 0.19 & 0.25 & 0.15 & 0.08 & ND & ND & ND \\
\hline$\sum$ AGS & 11.10 & 15.20 & 10.80 & 7.90 & 43.1 & 14.70 & 10.80 & 21.42 \\
\hline C16:1 & ND & 0.12 & 0.08 & 0.2 & 0.14 & 1.09 & ND & 6.60 \\
\hline C18:1 $\omega-9$ & 21.36 & 33.04 & 25.15 & 61.14 & 39.86 & 74.01 & 18.00 & 9.98 \\
\hline C20:1 & ND & 0.23 & 0.18 & 1.11 & 0.24 & 0.25 & ND & 1.08 \\
\hline$\sum$ MUFA & 21.36 & 33.4 & 25.4 & 62.6 & 40.1 & 75.35 & 18.00 & 17.66 \\
\hline C20:2 & ND & ND & ND & ND & ND & ND & ND & 3.05 \\
\hline C18:2 $\omega-6$ & 60.75 & 49.94 & 62.22 & 20.87 & 15.69 & 8.74 & 12.71 & 2.78 \\
\hline$C 20: 4 \omega-6$ & ND & ND & ND & ND & ND & ND & ND & 0.73 \\
\hline $\mathrm{C} 22: 2 \omega-6$ & ND & ND & ND & ND & ND & ND & ND & 0.87 \\
\hline $\mathrm{C} 18: 3 \omega-3$ & 6.96 & 0.96 & 0.32 & 6.78 & 0.83 & 0.75 & 58.47 & 0.80 \\
\hline C20:5 $\omega-3$ & ND & ND & ND & ND & ND & ND & ND & 24.01 \\
\hline$C 22: 6 \omega-3$ & ND & ND & ND & ND & ND & ND & ND & 19.86 \\
\hline$\sum$ PUFA & 67.71 & 50.90 & 62.6 & 28.4 & 16.6 & 9.50 & 71.18 & 52.10 \\
\hline Total $\omega-6$ & 60.75 & 49.94 & 62.22 & 20.87 & 15.69 & 8.74 & 12.71 & 4.37 \\
\hline Total $\omega-3$ & 6.93 & 0.96 & 0.32 & 6.78 & 0.83 & 0.75 & 58.47 & 44.63 \\
\hline$\omega-6 / \omega-3$ & 8.77 & 52.0 & 195.0 & 3.01 & 18.9 & 11.65 & 0.22 & 0.10 \\
\hline
\end{tabular}

aFatty acid concentration in soybean, corn, sunflower, canola, olive, flaxseed and fish oils. The identification of the methyl esters of the fatty acids was performed by gas chromatography. Values are in g/100 g. *ND= not determined. Source: (1) (ROSA, SALES et al., 2010) (2) (TACO, 2006).

Table 1. Concentration of fatty acids in the oils used in the diets (percent).

The importance of PUFAs in human nutrition relates to their role in modulating inflammatory responses, which in turn is related to immunological resistance, metabolic disturbances, thrombotic events and neoplasia (Martin, Almeida et al. 2006; Hirayama, Speridião et al. 2006). The $\omega-6$ and $\omega-3$ fatty acids are not metabolically interconvertable but because both share enzymatic pathways and usually play opposite effects, their balance or proportion seems to be important (Whelan \& McEntee 2004).

According to Willet (2001), non-cancer outcomes can aid in interpreting findings for cancer, especially when an association is observed with coronary heart disease, and any actual dietary decisions should be made in the light of not just cancer, but how dietetic variables relate to cardiovascular disease (CVD) and other important conditions. Evidences suggest that when increasing $\omega-3$ intake (EPA and DHA), the incidence of CVD is reduced, but 
opinions are still divergent on whether the same effects can be obtained with the reduction of $\omega-6$ intake. It is worthy to note that there are ethnic differences in the percentage of deaths from CVD when comparing Europe and the US (45\%) with Japan (12\%) which are coincident with significant differences in platelet phospholipid EPA concentration $(0.5 \%$ vs $1.6 \%$ ), while AA concentration is similar (26\% vs $21 \%$ ) (Russo 2009). Thus, the moderate consumption of fatty acids from the $\omega-3$ family, especially from fish oil, plays an important role on the reduction of CVD risks. Considerable attention has been directed to evaluate the action of ALA, EPA and DHA in the prevention and treatment of diseases in general. The American Heart Association (AHA) recommends the use of 1g/day of $\omega-3$ (EPA plus DHA) from fish oil or fatty fish to patients with CVD (Lavie, Milani et al. 2009).

In 2007, Von Schacky and Harris proposed the " $\omega-3$ index" as a new risk factor for cardiac disease. This index is defined as the percentage of EPA plus DHA of the total fat content in erythrocytes, reflecting the individual $\omega-3$ status. Although the authors have shown evidences that support the clinical efficacy of this index, it hasn't been validated as a biomarker. The PUFA content in cell membranes depends on diet content and its proportion of $\omega-6$ and $\omega-3$ fatty acids, although an optimal proportion still hasn't been established (von Schacky \& Harris 2007).

\section{PUFAs and colorectal carcinogenesis}

Biological effects on CRC promotion by $\omega-6$ PUFA or suppression by $\omega-3$ PUFA has been suggested by experimental and epidemiological studies (Nkondjock, Shatenstein et al. 2003; Moreira, Sabarense et al. 2009; Rosa, Sales et al. 2010; West, Clark et al. 2010). These effects include alteration in properties of cancer cells (proliferation, invasion, metastasis, and apoptosis) and host cells (inflammation, immune response and angiogenesis) (Larsson, Kumlin et al. 2004; Roynette, Calder et al. 2004).

These effects are mediated by various mechanisms. It has recently been shown that polymorphisms in fatty acid metabolism-related genes are associated with CRC risk. Although their contribution to CRC is not fully explained, they reinforced the key role of eicosanoid signaling in colon carcinogenesis (Hoeft, Linseisen et al. 2010). These eicosanoids are end-products of cell membrane fatty acids mobilization. The PUFA, LA and ALA are mobilized from cell membrane phospholipids through the action of phospholipases $A_{2}$ and $C$ enzymes. They then compete for desaturases and elongases enzymes for conversion to their metabolites, AA and EPA respectively. These enzymes have a greater affinity for $\omega-3$ fatty acids, such that $\omega-3$ are preferentially metabolized when its intake in the diet is high. This leads to a "competitive inhibition" of $\omega-6$ PUFA metabolism, decreasing LA desaturation and AA concentration after ALA, EPA or DHA supplementation. On the other hand, increases in $\omega-6$ will reduce EPA and DHA conversion (Roynette, Calder et al. 2004).

After mobilization from the cell membrane and AA or EPA formation, these fatty acids are subsequently metabolized into eicosanoids by the action of cyclooxygenase (COX) and lipoxygenase (LOX). Eicosanoids such as prostanoids (prostaglandins and thromboxanes), and leukotrienes are potent modulators of inflammatory and immune responses playing a critical role on platelet aggregation, cellular growth and differentiation. The COX action results in prostaglandins and thromboxanes, while the LOX produces leukotrienes. Eicosanoids are derived from fatty acids with 20 carbon atoms such as AA and EPA (Larsson, Kumlin et al. 2004; Berquin, Edwards et al. 2008), a step where there is also another competition among PUFA where there is a greater affinity for the $\omega-3$ PUFA. Thus, 
EPA is preferentially metabolized and consequently eicosanoids from series 3 (prostaglandins and thrombaxanes) and 5 (leukotrienes) will be produced. The proportion of PUFA in the cell membranes is the main factor regulating which eicosanoids will be produced, and this proportion reflects the amount of PUFA present in the diet (Rose \& Connolly 1999; Moreira, Sabarense et al. 2009; Russo 2009).

Increase in $\omega-6$ fatty acids in the western diet contributes to greater production of eicosanoids from AA rather than from EPA, which are associated with an decreased rate of apoptosis and a increased tumoral growth, and are also more reactive compared to proinflammatory eicosanoids derived from EPA (Roynette, Calder et al. 2004); eicosanoids from AA are biologically active even in small amounts. Lee et al. (1984) demonstrated that leukotriene $\mathrm{B}_{5}$ has only 5 to $10 \%$ of the activity of leukotriene $\mathrm{B}_{4}$ (from AA). If AA eicosanoids are formed in greater quantities, especially with a diet rich in $\omega-6$ fatty acids, it shifts the physiological state to a prothrombotic, proaggregation and pro-inflammatory condition (Simopoulos 2008), while the increase in $\omega-3$ intake could result in the reduction of the pro-inflammatory state (West, Clark et al. 2010).

As eicosanoid production influences carcinogenesis, the isoform of the enzyme producing them also play a role. There are two isoforms of COX: COX-1, which is constitutively expressed in many tissues, and COX-2, which is the inducible form. COX-2 expression occurs in most tissues, but after stimulus its expression can increase considerably (Zha, Yegnasubramanian et al. 2004). Elevated levels of COX-2 have been observed in colon tumors in humans and animals by chemically induced carcinogenesis (Shao, Sheng et al. 1999; Ceccarelli, Piazzi et al. 2005). This increase in COX-2 indicates an increase in the capacity to produce prostaglandin $\mathrm{E}_{2}\left(\mathrm{PGE}_{2}\right)$ in the presence of $\mathrm{AA}$. The $\mathrm{PGE}_{2}$ can promote carcinogenesis through the inhibition of apoptosis, induction of cell proliferation and angiogenesis (Leahy, Ornberg et al. 2002; Pai, Nakamura et al. 2003). Singh et al. (1997) induced CRC in rats and found elevation of COX-2 expression in the group treated with corn oil compared to the group receiving fish oil, indicating that $\omega-6$ rich oils participates in this mechanism.

A significant correlation was found between inducible nitric oxide synthase (iNOS) enzyme and COX-2 expression. The $\mathrm{PGE}_{2}$ production also correlated with iNOS activity (Cianchi, Cortesini et al. 2004). The iNOS is responsible for the synthesis of nitric oxide (NO) from Larginine. The NO mediates intra and extracellular processes; however, it is potentially toxic since it can react with oxygen or superoxides, damaging tissues and DNA. The activation of iNOS and the subsequent excess of NO production can also inhibit the activity of enzymes related to DNA repair and modulate caspases and p53 activity (Jaiswal, LaRusso et al. 2000). A significant correlation was found between iNOS and COX-2 expression. The PGE 2 production also correlated with iNOS activity (Cianchi, Cortesini et al. 2004). Another correlation found was between iNOS and angiogenesis in patients with CRC (Cianchi, Cortesini et al. 2003). Narayanan et al. (2003) showed that DHA can reduce iNOS expression in vitro. Reduction of the endogenous level of $\omega-6$ PUFA is beneficial since lower expression of the iNOS enzyme and increased expression of the transforming growth factor beta (TGF$\beta$ ) in transgenic animal model chemically submitted to CRC was observed (Nkondjock, Shatenstein et al. 2003). Reduction of TGF- $\beta$ expression has been shown to significantly increase chemically-induced colon carcinogenesis (Tang, Böttinger et al. 1998). On a molecular level, TGF- $\beta$ was shown to inhibit transformation through inhibition of the Akt pathway in intestinal epithelial cells (Cao, Deng et al. 2006). Therefore, $\omega-6$ fatty acids again appear to exert a negative influence on induction of enzymes related to carcinogenesis and reduction of protective molecules. 
The $\omega-6$ and $\omega-3$ PUFAs can also influence colorectal carcinogenesis by affecting expression of genes associated with vital functions of the cell, enzymes activities and signal transduction molecules. Cellular proliferation (mitosis) and growth are important aspects of tumors development when they occur uncontrolled. In this situation, the induced cell death through apoptosis is activated, which is recognized as an anti-carcinogenesis mechanism. When this mechanism fails, tumors can develop (Arlt, Müerköster et al. 2010).

The activated Ras protein regulates mitosis, and its increased expression is related to tumor development (Mangues, Seidman et al. 1992). Diets containing greater proportions of $\omega-6$ (corn oil) increases the expression of Ras protein by $13 \%$ in the colonic mucosa of rats treated with azoxymethane in comparison to animals receiving a diet rich in $\omega-3$ (fish oil) (Davidson, Lupton et al. 1999). Cellular growth can be promoted by insulin-like growth factor (IGF) through autocrine and paracrine actions, and IGF binding proteins (IGFBP) modulate IGF actions. Increases in IGF-II expression was demonstrated in patients with CRC (Freier, Weiss et al. 1999), while treatment of Caco-2 cells with EPA or DHA reduced IGF-II secretion and increased IGFBP-6 secretion, inhibiting cellular proliferation. On the other hand, LA can increase the level of IGF-II without altering IGFBP-6 secretion and stimulate Caco-2 cell proliferation (Kim, J. et al. 2000). It has also been suggested that hyperinsulinemia and insulin resistance can play a significant role in CRC etiology (Trevisan, Liu et al. 2001; Ma, Giovannucci et al. 2004). Insulin acts as growth factor for colonic cells because it enhances IGF-I activity, cell proliferation and differentiation, and inhibits apoptosis (Biddinger \& Ludwig 2005; Giovannucci 2007). Smith et al. (2010) demonstrated that reduction of the $\omega-6: \omega-3$ ratio can increase glucose tolerance and improve insulin sensitivity in healthy animals.

Meanwhile, the expression of some proteins related to apoptosis can be beneficial. The type of oil, and consequently its fatty acid profile, can exert different influences on protein expression. Cancerous cells usually overexpress $\mathrm{Bcl}-2$ proteins involved in apoptosis inhibition (Bronner, Culin et al. 1995 ), so that reduced expression could be beneficial. In cultured human cancer cells (Caco 2 and HT-29) supplemented with olive oil, fish oil, oleic fatty acid and LA, it was verified that $B c l-2$ expression was reduced in cells supplemented with EPA and DHA (fish oil group) (Llor, Pons et al. 2003). Moreover, Cheng et al. (2003) found an elevation in Bax protein expression, associated with the increase in apoptotic cell activity in individuals with CRC who consumed greater quantities of fish oil. Signaling molecules such as the transcriptional factor $N F \kappa \beta$ have been shown to play a role in carcinogenesis once it regulates the expression of genes involved in migration, proliferation and apoptosis (Dolcet, Llobet et al. 2005). Reduction of the endogenous level of $\omega-6$ PUFA led to lower $N F \kappa \beta$ activity in transgenic animal models chemically submitted to CRC (Nowak, Weylandt et al. 2007). Ravasco et al. (2009) also observed that patients with elevated intake of $\omega-6$ PUFA, saturated fat, animal protein, refined carbohydrates and alcohol - a typical western diet - present greater expression of this transcriptional factor. However, patients with higher $\omega-3$, fibers, vitamin $\mathrm{E}$, isoflavonoid, $\beta$-carotene and selenium

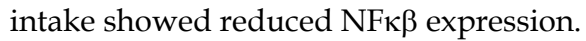

Another mechanism that links apoptosis, PUFA and CRC development refers to the peroxisome proliferator-activated receptor (PPAR). DHA and EPA (in lesser extent) can inhibit PPAR- $\delta$ which is associated with the increase in cell proliferation and apoptosis suppression (Lee \& Hwang 2002; Lund 2006; Wang \& DuBois 2008). On the other hand, Xu et al. (2006) demonstrated that AA can act as an activator of PPAR- $\delta$. Thus, sources of $\omega-6$ 
fatty acids appear to be disadvantageous for cancer prevention while $\omega-3$ fatty acids are beneficial.

The PUFA have also demonstrated to influence the activity of the enzyme ornithine decarboxylase (ODC), which is a limiting enzyme in polyamines synthesis (putrescin, spermidin and spermine). These polyamines are involved in cellular growth, renewal and metabolism, and have been found in high concentrations in colorectal tumors of rats treated with dimethylhydrazine and humans due to increased ODC activity (Lamuraglia, Lacaine et al. 1986; Shigesawa, Onoda et al. 1998). Bastram et al. (1993) observed a reduction in ODC activity in the colon of healthy individuals consuming fish oil compared with corn oil (rich in LA). Rao and Reddy (1993) encountered results reinforcing the role of $\omega-3$ fatty acids from fish oil in suppressing ODC activity in animal models of carcinogenesis in comparison to $\omega-$ 6 fatty acids from corn oil.

It can be highlighted that the suppressive effects of EPA and DHA on CRC tumors are consistently verified, while ALA effects are still controversial (Daniel, McCullough et al. 2009). This inconsistency can be related to the small conversion of ALA to EPA, which requires further investigations (Berquin, Edwards et al. 2008). In relation to the adverse effects from $\omega-3$ PUFA intake, it is important to highlight that these fatty acids present a greater number of double bonds (unsaturations) which makes cell membranes more susceptible to lipid peroxidation. Thus, it is recommended to increase the intake of antioxidant vitamins to compensate for the increase in PUFA intake, mainly $\omega-3$, in order to stabilize the double bonds (Institute of Medicine 2000).

However, it is not correct to consider that all mediators formed from AA are proinflammatory while those formed from EPA are always less potent. The action of $\omega-6$ and $\omega-$ 3 fatty acids and their derivatives on inflammatory processes can actually involve more complex mechanisms than those already recognized and requires more studies to clarify their mechanisms and effects (Calder 2009).

\section{PUFA intake recommendations}

The $\omega-3$ long chain fatty acids (LCFA), EPA and DHA, have received special attention as a recommended nutrient for secondary prevention of CVD and for the prevention and treatment of disorders with an inflammatory component (including type 2 diabetes, irritable bowel syndrome, macular degeneration, rheumatoid arthritis, asthma, several cancers, and psychiatric disorders) since these illnesses have shown to be a problem around the world (Hibbeln et al, 2006). The high $\omega-6: \omega-3$ ratio is unfavorable, especially in health conditions characterized by aggravation of the inflammatory response (Garofolo \& Petrilli 2006). There are some studies associating PUFAs and CRC in humans suggesting a possible protective role of $\omega-3$ in this disease (Table 2).

Establishing healthy $\omega-6$ and $\omega-3$ intakes is difficult since there are various factors influencing optimal intake. Hibbeln et al. (2006) discussed these aspects in an ecological study design. Some of their considerations are very important to be discussed in this chapter to aid in answering whether soybean oil has a positive or negative health effects in comparison with other oils.

1. A tissue composition of $60 \% \omega-3$ LCFA may prevent $98.6 \%$ of the worldwide risk of cardiovascular mortality potentially attributable to $\omega-3$ LCFA deficiency. However, the $\omega-3$ LCFA intake required to achieve $60 \% \omega$-3 fatty acids in tissue varied 13 -fold among nations depending on essential fatty acid availability. In general, as concurrent LA 
availability increased, the estimated requirement for $\omega-3$ LCFA intake increased, although intake of ALA and AA also played a role. For Americans consuming a 2000$\mathrm{kcal} / \mathrm{d}$ diet, $2178 \mathrm{mg} / \mathrm{d}$ (0.98\% of energy) may achieve 50\% $\omega-3$ LCFA in tissue, whereas $3667 \mathrm{mg} / \mathrm{d}$ is necessary to reach $60 \% \omega-3 \mathrm{LCFA}$.

2. Available intake of $\omega-3$ LCFA to provide $0.34 \%$ of energy was sufficient to reduce risk for $98 \%$ of the mortality and morbidity in all illness models.

3. Lowering LA intake can likely decrease an individual's need for $\omega-3$ LCFAs by onetenth.

4. Concurrent dietary intakes of LA, AA, ALA, EPA and DHA should be considered in predicting final tissue proportions of $\omega-3$ LCFAs. Thus, a healthy dietary intake of $\omega-3$ LCFA must be dependent on concurrent intakes of LA, AA and ALA. A healthy dietary allowance of $3.5 \mathrm{~g}$ EPA plus DHA/d, which is based on the current per capita available intake of $\omega-6$ fatty acids and ALA in the US, could be reduced to one-tenth of that amount if the intake of $\omega-6$ fatty acids, in particular LA, can be lowered to $2 \%$ of the total energy.

Based on a critical analysis of available literature, Wijendran and Hayes (2004) suggest for health adults an adequate intake of about $6 \%$ of total calories from LA, $0.75 \%$ from ALA, and $0.25 \%-0.5 \%$ for EPA plus DHA. This corresponds to an $\omega-6: \omega-3$ ratio of $6: 1$. According these authors, intake of PUFA expressed in terms of mass (\% $\mathrm{kcal}$ or $\mathrm{g} / \mathrm{d})$ is a better approach to dietary $\omega-6$ and $\omega-3$ fatty acid balance than a simple ratio.

Therefore, choosing the best oil to cook or to add in food products should consider its lipid profile and how much of it is used.

\begin{tabular}{llcl}
\hline Reference & Study Design & $\begin{array}{c}\text { Comparative } \\
\text { Indicator }\end{array}$ & Results \\
\hline
\end{tabular}

\begin{tabular}{|c|c|c|c|}
\hline \multicolumn{4}{|c|}{ Linoleic Acid (LA, $\omega-6)$} \\
\hline $\begin{array}{l}\text { Tuyns et al. } \\
\text { (1987) }\end{array}$ & $\begin{array}{l}\text { Case-control } \\
818 \text { cases } / 2851 \text { controls }\end{array}$ & Food Intake & $\begin{array}{l}\text { Inverse association } \\
\text { between LA and cancer }\end{array}$ \\
\hline Bar et al. (1998) & $\begin{array}{l}\text { Cross-sectional } \\
17 \text { cases / } 12 \text { controls }\end{array}$ & $\begin{array}{l}\text { Fatty acids in } \\
\text { plasma }\end{array}$ & $\begin{array}{l}\text { Significant } \downarrow \text { LA in } \\
\text { cancer patients }\end{array}$ \\
\hline $\begin{array}{l}\text { Terry et al. } \\
(2001)\end{array}$ & $\begin{array}{l}\text { Cohort - Sweden } \\
61463 \text { women }\end{array}$ & Food Intake & No relationship \\
\hline Astorg (2005) & $\begin{array}{l}\text { Meta Analysis } \\
\text { Epidemiological research }\end{array}$ & Food Intake & No relationship \\
\hline Hall et al. (2007) & $\begin{array}{l}\text { Case-Control (Physicians' } \\
\text { Health Study). } 178 \text { case } \\
\text { men/ } 282 \text { control men }\end{array}$ & Blood Levels & No relationship \\
\hline $\begin{array}{l}\text { Theodoratou et } \\
\text { al. (2007) }\end{array}$ & $\begin{array}{l}\text { Prospective case-control } \\
\text { study } 1455 \text { cases/ } 1455 \\
\text { controls }\end{array}$ & Food Intake & No relationship \\
\hline $\begin{array}{l}\text { Murff et al. } \\
(2009)\end{array}$ & $\begin{array}{l}\text { Cohort Study (Study } \\
\text { Shanghai Women's Health) } \\
73242 \text { woman }\end{array}$ & Food Intake & No relationship \\
\hline
\end{tabular}




\begin{tabular}{|c|c|c|c|}
\hline Reference & Study Design & $\begin{array}{l}\text { Comparative } \\
\text { Indicator }\end{array}$ & Results \\
\hline \multicolumn{4}{|c|}{$\alpha$-Linolenic Acid $(A L A, \omega-3)$} \\
\hline $\begin{array}{l}\text { Fernández- } \\
\text { Bañares et al. } \\
\text { (1996) }\end{array}$ & $\begin{array}{l}\text { Cross-sectional } \\
49 \text { CRC cases / } 12 \text { controls }\end{array}$ & $\begin{array}{l}\text { Mucosal fatty } \\
\text { acids }\end{array}$ & $\begin{array}{l}\text { Significant } \downarrow \text { ALA in } \\
\text { intestine mucosal of } \\
\text { cancer patients }\end{array}$ \\
\hline Bar et al. (1998) & $\begin{array}{l}\text { Cross-sectional } \\
17 \text { CRC cases / } 12 \text { controls }\end{array}$ & Fatty acids & $\begin{array}{l}\text { Significant } \downarrow \text { ALA in } \\
\text { plasma of cases }\end{array}$ \\
\hline $\begin{array}{l}\text { Nkondjock et al. } \\
\text { (2003) }\end{array}$ & $\begin{array}{l}\text { Case-control } \\
402 \text { cases } / 668 \text { controls }\end{array}$ & Food Intake & $\begin{array}{l}\text { Significant inverse } \\
\text { association between } \\
\text { ALA and CRC }\end{array}$ \\
\hline $\begin{array}{l}\text { Terry et al. } \\
(2001)\end{array}$ & $\begin{array}{l}\text { Cohort }(1987-1990) \\
61463 \text { women }\end{array}$ & Food Intake & No relationship \\
\hline Astorg (2005) & $\begin{array}{l}\text { Meta Analysis } \\
\text { Epidemiological Research }\end{array}$ & Food Intake & No relationship \\
\hline $\begin{array}{l}\text { Theodoratou et } \\
\text { al. (2007) }\end{array}$ & $\begin{array}{l}\text { Prospective case-control } \\
\text { study } 1455 \text { cases } / 1455 \\
\text { controls }\end{array}$ & Food Intake & No relationship \\
\hline $\begin{array}{l}\text { Murff et al. } \\
\text { (2009) }\end{array}$ & $\begin{array}{l}\text { Cohort Study (Study } \\
\text { Shanghai Women's Health) } \\
73242 \text { women }\end{array}$ & Food Intake & No relationship \\
\hline
\end{tabular}

\begin{tabular}{|c|c|c|c|}
\hline \multicolumn{4}{|c|}{ Eicosapentaenoic acid plusDocosahexanoic Acid (EPA/DHA, $\omega-3)$} \\
\hline $\begin{array}{l}\text { Jiang et al. } \\
(2010)\end{array}$ & $\begin{array}{l}\text { Randomized clinical trial } \\
\text { Intravenous infusion of } \\
\text { soybean oil or fish oil } \\
203 \text { cases }\end{array}$ & $\begin{array}{c}\text { Inflammatory } \\
\text { response and } \\
\text { lenght of hospital } \\
\text { stay }\end{array}$ & Significant $\downarrow$ in fish oil \\
\hline Hall et al. (2007) & $\begin{array}{l}\text { Case-Control (Physicians' } \\
\text { Health Study) } 178 \text { case } / 282 \\
\text { control (men) }\end{array}$ & Blood Levels & $\begin{array}{l}\text { EPA and DHA were } \\
\text { inversely associated } \\
\text { with CRC risk }\end{array}$ \\
\hline $\begin{array}{l}\text { Theodoratou et } \\
\text { al. (2007) }\end{array}$ & $\begin{array}{l}\text { Prospective case-control.1455 } \\
\text { cases/ } 1455 \text { controls }\end{array}$ & Food Intake & $\begin{array}{l}\text { Significant } \downarrow \text { in the risk } \\
\text { were associated } \\
\text { with } \uparrow \text { EPA and DHA } \\
\text { intake }\end{array}$ \\
\hline Kin et al. (2010) & $\begin{array}{l}\text { Case-control } \\
929 \text { cases } / 943 \text { controls }\end{array}$ & Food Intake & $\begin{array}{l}\text { Inverse association } \\
\text { between EPA, DHA and } \\
\text { CRC }\end{array}$ \\
\hline Gee et al. (1999) & $\begin{array}{l}\text { Case-control } \\
14 \text { cases } / 14 \text { controls }\end{array}$ & $\begin{array}{l}\text { Colorectal } \\
\text { cytokinetics }\end{array}$ & No relationship \\
\hline Terry et al. & Cohort-Sweden (1987-1990), & Food Intake & No Relationship \\
\hline
\end{tabular}




\begin{tabular}{|c|c|c|c|}
\hline Reference & Study Design & $\begin{array}{l}\text { Comparative } \\
\text { Indicator }\end{array}$ & Results \\
\hline$(2001)$ & 61463 women & & \\
\hline Astorg (2005) & $\begin{array}{l}\text { Meta Analysis } \\
\text { Epidemiological research }\end{array}$ & Food Intake & No relationship \\
\hline $\begin{array}{l}\text { Murff et al. } \\
\text { (2009) }\end{array}$ & $\begin{array}{l}\text { Cohort (Study Shanghai } \\
\text { Women's Health), } 73242 \\
\text { women }\end{array}$ & Food Intake & No Relationship \\
\hline Oh et al.(2005) & $\begin{array}{l}\text { Cohort (Nurses' Health } \\
\text { Study) 34451women }\end{array}$ & Food Intake & No relationship \\
\hline \multicolumn{4}{|c|}{ Eicosapentaenoic acid $(E P A, \omega-3)$} \\
\hline $\begin{array}{l}\text { Fernández- } \\
\text { Bañares et } \\
\text { al.(1996) }\end{array}$ & $\begin{array}{l}\text { Cross-sectiiional } \\
49 \text { cases CCR/12 controls }\end{array}$ & $\begin{array}{l}\text { Mucosal Fatty } \\
\text { acids }\end{array}$ & $\begin{array}{l}\text { Significant } \downarrow \text { in } \\
\text { intestine mucosal EPA } \\
\text { content in cancer } \\
\text { patients }\end{array}$ \\
\hline $\begin{array}{l}\text { Courtney et } \\
\text { al.(1996) }\end{array}$ & $\begin{array}{l}\text { Case-control } \\
14 \text { cases/14 controls }\end{array}$ & $\begin{array}{l}\text { Apoptosis and } \\
\text { crypt cell } \\
\text { proliferation }\end{array}$ & $\begin{array}{l}\text { Significantly } \downarrow \text { in } \\
\text { cancer patients }\end{array}$ \\
\hline Hall et al.(2008) & $\begin{array}{l}\text { Prospective Study } \\
\text { (Physicians' Health Study), } \\
500 \text { men }\end{array}$ & Food Intake & $\begin{array}{l}\text { EPA significantly } \downarrow \text { the } \\
\text { risk for CCR }\end{array}$ \\
\hline West et al.(2010) & $\begin{array}{l}\text { Clinical Trial } \\
55 \text { patients }\end{array}$ & $\begin{array}{l}\text { The number and } \\
\text { size of polyps }\end{array}$ & $\begin{array}{l}\text { Protective effect of EPA } \\
\text { in colon cancer patients }\end{array}$ \\
\hline \multicolumn{4}{|c|}{ Docosahexanoic Acid (DHA, $\omega-3)$} \\
\hline $\begin{array}{l}\text { Kuriki et } \\
\text { al.(2006) }\end{array}$ & $\begin{array}{l}\text { Case-control } \\
74 \text { cases } / 221 \text { controls }\end{array}$ & $\begin{array}{l}\text { Erythrocyte fatty } \\
\text { acids }\end{array}$ & $\begin{array}{l}\text { Inverse association } \\
\text { between erythrocyte } \\
\text { compositions and DHA }\end{array}$ \\
\hline Hall et al.(2007) & $\begin{array}{l}\text { Case-Control (Physicians' } \\
\text { Health Study), } 178 \\
\text { case/282control }\end{array}$ & Blood Levels & $\begin{array}{l}\text { DHA were inversely } \\
\text { associated with CRC } \\
\text { risk }\end{array}$ \\
\hline
\end{tabular}

Table 2. Human studies examining the effect of $\omega-6$ and $\omega-3$ PUFAs on colorectal cancer risk

\section{Future perspectives}

Sufficient evidence was shown to portray the shift in concern on the role of dietary fat in carcinogenesis: from the amount of fat consumed to the type of fat (fatty acids profile), that is, $\omega-3$ vs $\omega-6$ PUFAs. Most evidence for benefits apply to the $\omega-3$ LCFAs. Considering this, two problems are indicated: western diets are typically low in EPA and DHA because consumption of the primary source of these fatty acids from oily fish (such as salmon, mackerel, albacoretuna, and sardines) is low (Harris, Lemke et al. 2008) and it is problematic 
to recommend to patients or the community to increase fish intake due to price and availability of oily fish (James, Ursin et al. 2003). Because conversion of dietary ALA into EPA is limited and a fish/fish oil based diet is not easily adopted, dietetic solutions to this limitation should provide great perspectives for the future.

Some vegetables oils are good sources of $\omega-3$, such as canola and linseed oils, but in the ALA form. However, conversion of ALA to EPA is inefficient in adult humans and increased intake of ALA does not reproduce the health benefits of $\omega-3$ LCFAs. Initially, it is generally assumed that LA reduces EPA synthesis because of the competition between ALA and LA for common desaturation and elongation enzymes. Hence, one of the dietetic solutions thought to favor the conversion of ALA into the $\omega-3$ LCFA would be the increase of ALA intake or decrease of LA intake. Goyens et al. (2006) designed a nutritional intervention trial to determine whether in vivo conversion of dietary ALA is influenced by the absolute amounts of LA or ALA in the diet or by the ALA-to-LA ratio. They concluded that ALA and LA content in the diet, and not its ratio, determines the conversion of ALA into EPA/DHA, suggesting that the increase in DHA is directly related to ALA content in the diet, while EPA formation is favored by reduced LA levels in the diet (Goyens, Spilker et al. 2006).

Besides reducing dietary intakes of the 18-carbon precursor, LA lowers the available tissue composition of AA. According to Hibbeln et al. (2006), it is likely that the success and failure of different clinical trials using similar doses of $\omega-3$ LCFAs may have been influenced by differing background intakes of the $\omega-6$ LA and AA fatty acids. The biological availability and activity of $\omega-6$ LCFAs, in particular AA, is inversely related to $\omega-3$ LCFAs in tissue. Greater compositions of EPA and DHA in membranes competitively lower the availability of AA for the production of inflammatory eicosanoids.

A useful land-based dietary resource for increasing tissue concentrations of $\omega-3$ LCFAs in humans would be of great economical interest to provide a wide range of dietary alternatives to fish and encapsulated fish oil supplements to increase tissue concentrations of $\omega$-3 LCFAs without altering common dietary habits. Stearidonic acid (SDA, 18:4 $\omega-3$ ) rich oils could provide this potential land solution, since it has also been studied as a precursor for $\omega-3$ LCFAs in humans. SDA is an intermediate metabolite between ALA and EPA in the $\omega-3$ biosynthetic pathways. It has been shown that ALA in the diet is converted to EPA, with only a fraction of the efficiency of SDA in healthy subjects (James, Ursin et al. 2003). Further, $\Delta-6$ activity has been shown to decline with age (Bourre, Piciotti et al., 1990) and with a significant number of clinical conditions, such as cancer, making utilization of dietary ALA even less efficient (Damude \& Kinney 2008).

Recently, soybean plants have been genetically modified to produce oil containing a substantial amount of SDA (15-30\% w/w of total fatty acids) with value in both food and feed applications (Ursin 2003). Some studies are consistent with the premise that $\Delta 6$ desaturation is the rate-limiting step in the conversion of ALA to EPA and that SDA has a biochemical advantage over ALA in elevating the levels of others $\omega-3$ LCFAs in tissues. The efficiency of ALA conversion into EPA was shown to be $0.09 \%$, while SDA conversion was $16.6 \%$ (relative to EPA). Hence, another strategy for raising tissue EPA levels with a plantbased $\omega-3$ is to consume foods containing SDA (Harris, Lemke et al. 2008). James et al. (2003) showed greater enrichment of EPA in plasma and lipid cells if subjects supplemented their diet with ethyl ester of SDA than if supplemented with the same amount of the ethyl ester of 
ALA. Therefore, SDA appears to be superior to ALA for increasing $\omega-3$ LCFAs status in humans and thus sources of SDA might offer some human health benefits. Supplementation of SDA led to an elevated increase in EPA compared to ALA supplementation, but no increase in DHA. SDA also demonstrated to be superior to ALA for lowering the level of COX-2 protein and mRNA expression in breast cancer cells. Thus, the authors suggested that dietary SDA may be more beneficial than ALA in reducing the risk of breast cancer by effectively antagonizing $\mathrm{PGE}_{2}$ production from AA (Horia \& Watkins 2005).

It should be highlighted that the effectiveness of SDA as a nutritional fatty acid is dependent on the ability of humans and animals to convert SDA to EPA and DHA. Thus, the beneficial effects of EPA and DHA have incentivated the development of soybean seeds that accumulate oils with EPA and DHA. It is envisioned that these oils can be produced at a lower cost in soybean seeds compared with fish and algae, the current commercial sources of EPA and DHA-containing oils. Additionally, soybean offers a more sustainable production platform than fish. It is likely that soybean oil enriched in EPA and DHA is used in the manufacture of food and feed products, including salad oils, infant formulas, and feed rations for farm fish (Clemente \& Cahoon 2009). Thus, in relation to soy, the future strides in making a better bean.

\section{Conclusion}

Cancer, as said before, is a multifactorial disease. To blame fat as the only factor behind colorectal carcinogenesis would be irresponsibility, but it plays an important role in etiology for which public health campaigns and food manufacturers can discuss possible changes to benefit all.

Human studies evaluating dietary pattern to estimate risk factors are frequently difficult to interpret since individuals with healthier dietary patterns also present other healthier behaviour. On the other hand, experimental studies have contributed to comprehension of the relation between PUFAs and CRC and demonstrate that lower cancer progression is influenced by $\omega-3$ intake, mainly LCFA, while a higher progression is related to elevated $\omega-6$ intake. Thus, the ideal dietetic solution for a westernized dietary pattern would be the combination of an increase in $\omega-3$ LCFA and reduction of $\omega-6$ PUFA. More discussions regarding what unit to use to recommend fatty acid intake (\% of calories, g/d or $\omega-6: \omega-3$ ratio) should take into consideration the results of controlled studies.

If we consider that overconsumption of oils rich in $\omega-6$ can favour a pro-inflammatory state and predispose to the development of chronic diseases, such as CRC, sunflower oil, followed by soybean and corn oils are not the best type of oil to be used for cooking or added to food products. On the other hand, if we look to the $\omega-3$ level, soybean oil is similar to canola oil and superior than corn, sunflower and olive oil. The $\omega-3$ content of flaxseed and fish oil is so high that makes them inadequate for cooking or as food ingredient due to higher susceptibility to oxidation and formation of undesirable flavor. Considering this and the $\omega-6: \omega-3$ ratio in the others more usable oils, soybean oil would be the best choice for cooking after canola oil, even better if we take into account soybean oil prices in comparison to others oils.

Research investments have been made in order to improve fatty acid profile in the soybean and consequently in its oil, bringing new perspectives for this discussion. Genetic modifications allow that products provide a more balanced fatty acid profile as an alternative to the traditional soybean and these studies are under investigation, showing 
good potential with increased levels of SDA. This modification seems to overcome the main limitation of vegetable oils, which is the fact that although they are good sources of $\omega-3$ in the ALA form, the conversion to pharmacologically active compounds (EPA and DHA) is low. Besides, there is also a reduction of LA in the SDA rich soybean oil, which may help to reduce LA intake and consequently reduce the $\omega-3$ fatty acid needs. Although this genetically modified (OGM) soybean brings good perspectives in a clinical application point of view, the disadvantages or risks of using OGM's from other viewing angles should be also considered.

\section{Acknowledgment}

A special thanks to Evan Michael Visser for the revision of the English version of this Chapter.

\section{References}

Arlt, A., S. S. Müerköster, et al. (2010). Targeting apoptosis pathways in pancreatic cancer. Cancer Letters In Press, Corrected Proof.

Astorg, P. (2005). Acides gras alimentaires, cancer colorectal et cancer de la prostate : études épidémiologiques. Bulletin du Cancer 92(7): 670-684.

Baró, L., J. Hermoso, et al. (1998). Abnormalities in plasma and red blood cell fatty acid profiles of patients with colorectal cancer. British Joumal of Cancer 77(11): 1978-1983.

Bartram, H., A. Gostner, et al. (1993). Effects of fish oil on rectal cell proliferation, mucosal fatty acids and prostaglandin E2 release in healthy subjects. Gastroenterology 105(5): 13171322.

Berquin, I. M., I. J. Edwards, et al. (2008). Multi-targeted therapy of cancer by omega-3 fatty acids. Cancer Letters 269(2): 363-377.

Biddinger, S. B. and D. S. Ludwig (2005). The insulin-like growth factor axis: a potential link between glycemic index and cancer. The American Journal of Clinical Nutrition 82(2): 277-278.

Boateng, J., M. Verghese, et al. (2006). Red palm oil suppresses the formation of azoxymethane (AOM) induced aberrant crypt foci (ACF) in Fisher 344 male rats. Food and Chemical Toxicology 44(10): 1667-1673.

Bourre, J. M., M. Piciotti, et al. (1990). Delta-6-desaturase in brain and liver during development and aging. Lipids 25(6): 354-356.

Bronner, M., C. Culin, et al. (1995 ). The bcl-2 proto-oncogene and the gastrointestinal epithelial tumor progression model. Am J Pathol. 146(1): 20-26.

Calder, P. C. (2009). Polyunsaturated fatty acids and inflammatory processes: New twists in an old tale. Biochimie 91(6): 791-795.

Cao, Y., C. Deng, et al. (2006). TGF-beta inhibits Akt-induced transformation in intestinal epithelial cells. Surgery 140(2): 322-329.

Caughey, G., E. Mantzioris, et al. (1996). The effect on human tumor necrosis factor alpha and interleukin 1 beta production of diets enriched in n-3 fatty acids from vegetable oil or fish oil. American Journal of Clinical Nutrition 63(1): 116-122. 
Ceccarelli, C., G. Piazzi, et al. (2005). Concurrent EGFr and COX-2 expression in colorectal cancer: proliferation impact and tumour spreading. Annals Oncol. 16(4): 74-79.

Center, M. M., A. Jemal, et al. (2009). International Trends in Colorectal Cancer Incidence Rates. Cancer Epidemiology Biomarkers \& Prevention 18(6): 1688-1694.

Cheng, J., K. Ogawa, et al. (2003). Increased intake of n-3 polyunsaturated fatty acids elevates the level of apoptosis in the normal sigmoid colon of patients polypectomized for adenomas/tumors. Cancer Letters 193(1): 17-24.

Cianchi, F., C. Cortesini, et al. (2004). Cyclooxygenase-2 Activation Mediates the Proangiogenic Effect of Nitric Oxide in Colorectal Cancer. Clinical Cancer Research 10(8): 2694-2704.

Cianchi, F., C. Cortesini, et al. (2003). Inducible Nitric Oxide Synthase Expression in Human Colorectal Cancer: Correlation with Tumor Angiogenesis. The American Journal of Pathology 162(3): 793-801.

Clemente, T. E. and E. B. Cahoon (2009). Soybean Oil: Genetic Approaches for Modification of Functionality and Total Content. Plant Physiology 151(3): 1030-1040.

Coleman, L. J., E. K. Landström, et al. (2002). A Diet Containing alpha-Cellulose and Fish Oil Reduces Aberrant Crypt Foci Formation and Modulates Other Possible Markers for Colon Cancer Risk in Azoxymethane-Treated Rats. The Journal of Nutrition 132(8): 2312-2318.

Cordain, L. and S. Eaton (2005). Origins and evolution of the Western diet: health implications for the 21st century. The American Journal of Clinical Nutrition 81(2): 341-354.

Damude, H. G. and A. J. Kinney (2008). Enhancing Plant Seed Oils for Human Nutrition. Plant Physiology 147(3): 962-968.

Daniel, C. R., M. L. McCullough, et al. (2009). Dietary Intake of $\alpha-6$ and -3 Fatty Acids and Risk of Colorectal Cancer in a Prospective Cohort of U.S. Men and Women. Cancer Epidemiology Biomarkers \& Prevention 18(2): 516-525.

Davidson, L. A., J. R. Lupton, et al. (1999). Carcinogen and dietary lipid regulate ras expression and localization in rat colon without affecting farnesylation kinetics. Carcinogenesis 20(5): 785-791.

Dolcet, X., D. Llobet, et al. (2005). NF-kB in development and progression of human cancer. Virchows Archiv 446(5): 475-482.

Dwivedi, C., K. Natarajan, et al. (2005). Chemopreventive effects of dietary flaxseed oil on colon tumor development. Nutrition and Cancer 51(1): 52-58.

Ferlay, J., H. Shin, et al. (2010). "GLOBOCAN 2008, Cancer Incidence and Mortality Worldwide: ." http://globocan.iarc.fr. Retrieved 02/15/2011, 2011.

Fernández-Bañares, F., M. Esteve, et al. (1996). Changes of the mucosal n3 and n6 fatty acid status occur early in the colorectal adenoma-carcinoma sequence. Gut 38(2): 254-259.

Flood, A., T. Rastogi, et al. (2008). Dietary patterns as identified by factor analysis and colorectal cancer among middle-aged Americans. The American Journal of Clinical Nutrition 88(1): 176-184.

Flood, A., E. M. Velie, et al. (2003). Meat, Fat, and Their Subtypes as Risk Factors for Colorectal Cancer in a Prospective Cohort of Women. American Journal of Epidemiology 158(1): 59-68. 
Freier, S., O. Weiss, et al. (1999). Expression of the insulin-like growth factors and their receptors in adenocarcinoma of the colon. Gut 44(5): 704-708.

Fung, T., F. B. Hu, et al. (2003). Major Dietary Patterns and the Risk of Colorectal Cancer in Women. Arch Intern Med 163(3): 309-314.

Garófolo, A. and A. S. Petrilli (2006). Balanço entre ácidos graxos ômega-3 e 6 na resposta inflamatória em pacientes com câncer e caquexia. Revista de Nutrição 19: 611-621.

Gee, J. M., M. Watson, et al. (1999). Consumption of Fish Oil Leads to Prompt Incorporation of Eicosapentaenoic Acid into Colonic Mucosa of Patients Prior to Surgery for Colorectal Cancer, But Has No Detectable Effect on Epithelial Cytokinetics. The Journal of Nutrition 129(10): 1862-1865.

Giovannucci, E. (2007). Metabolic syndrome, hyperinsulinemia, and colon cancer: a review. The American Journal of Clinical Nutrition 86(3): 836S-842S.

Golbitz, P. (1995). Traditional Soyfoods: Processing and Products. The Journal of Nutrition 125(3 Suppl): 570S-572S.

Goyens, P. L., M. E. Spilker, et al. (2006). Conversion of $\alpha$-linolenic acid in humans is influenced by the absolute amounts of -linolenic acid and linoleic acid in the diet and not by their ratio. The American Journal of Clinical Nutrition 84(1): 44-53.

Hall, M. N., H. Campos, et al. (2007). Blood Levels of Long-Chain Polyunsaturated Fatty Acids, Aspirin, and the Risk of Colorectal Cancer. Cancer Epidemiology Biomarkers $\mathcal{E}$ Prevention 16(2): 314-321.

Hall, M. N., J. E. Chavarro, et al. (2008). A 22-year Prospective Study of Fish, n-3 Fatty Acid Intake, and Colorectal Cancer Risk in Men. Cancer Epidemiology Biomarkers $\mathcal{E}$ Prevention 17(5): 1136-1143.

Harris, W., S. Lemke, et al. (2008). Stearidonic Acid-Enriched Soybean Oil Increased the Omega-3 Index, an Emerging Cardiovascular Risk Marker. Lipids 43(9): 805-811.

Hawrylewicz, E. J., J. J. Zapata, et al. (1995). Soy And Experimental Cancer: Animal Studies. The Journal of Nutrition 125(3 Suppl): 698S-708S.

He, K. (2009). Fish, Long-Chain Omega-3 Polyunsaturated Fatty Acids and Prevention of Cardiovascular Disease--Eat Fish or Take Fish Oil Supplement? Progress in Cardiovascular Diseases 52(2): 95-114.

Hibbeln, J. R., L. R. Nieminen, et al. (2006). Healthy intakes of n-3 and n-6 fatty acids: estimations considering worldwide diversity. The American Journal of Clinical Nutrition 83(6): S1483-1493S.

Hirayama, K., P. Speridião, et al. ( 2006). Ácidos graxos polinsaturados de cadeia longa. The Electronic Journal of Pediatric Gastroenterology, Nutrition and Liver Diseases 10(3).

Hoeft, B., J. Linseisen, et al. (2010). Polymorphisms in fatty acid metabolism-related genes are associated with colorectal cancer risk. Carcinogenesis 31(3): 466-472.

Horia, E. and B. A. Watkins (2005). Comparison of stearidonic acid and [alpha]-linolenic acid on PGE2 production and COX-2 protein levels in MDA-MB-231 breast cancer cell cultures. The Journal of Nutritional Biochemistry 16(3): 184-192.

Institute of Medicine (2000). Dietary reference intakes (DRIs) for vitamin C, vitamin E, selenium, and carotenoids. Washington (DC), National Academy Press. 
Jaiswal, M., N. F. LaRusso, et al. (2000). Inflammatory Cytokines Induce DNA damage and Inhibit DNA repair in Cholangiocarcinoma Cells by a Nitric Oxide-dependent Mechanism. Cancer Research 60(1): 184-190.

James, M. J., V. M. Ursin, et al. (2003). Metabolism of stearidonic acid in human subjects: comparison with the metabolism of other n-3 fatty acids. The American Journal of Clinical Nutrition 77(5): 1140-1145.

Jemal, A., F. Bray, et al. (2011). Global cancer statistics. CA Cancer J Clin 7.

Jemal, A., R. Siegel, et al. (2010). Cancer Statistics, 2010. CA Cancer J Clin: caac.20073.

Jiang, Z. M., D. W. Wilmore, et al. (2010). Randomized clinical trial of intravenous soybean oil alone versus soybean oil plus fish oil emulsion after gastrointestinal cancer surgery. Br J Surg 97(6):804-809.

Kim, E. J., W.Y. Kim, et al. (2000). Inhibition of caco-2 cell proliferation by (n-3) fatty acids : Possible mediation by increased secretion of insulin-like growth factor binding protein-6. Nutrition research 20 (10):1409-1421.

Kim, S., D. P. Sandler, et al. (2010). Intake of Polyunsaturated Fatty Acids and Distal Large Bowel Cancer Risk in Whites and African Americans. American Journal of Epidemiology 171(9): 969-979.

Kuriki, K., K. Wakai, et al. (2006). Risk of Colorectal Cancer Is Linked to Erythrocyte Compositions of Fatty Acids as Biomarkers for Dietary Intakes of Fish, Fat, and Fatty Acids. Cancer Epidemiology Biomarkers \& Prevention 15(10): 1791-1798.

Labianca, R. and G. Beretta (2010). Colon cancer. Critical Reviews in Oncology/Hematology 74(2): 106-133.

Lamuraglia, G., F. Lacaine, et al. (1986). High ornithine decarboxylase activity and polyamine levels in human colorectal neoplasia. Ann Surg. 204(1): 89-93.

Larsson, S. C., M. Kumlin, et al. (2004). Dietary long-chain n-3 fatty acids for the prevention of cancer: a review of potential mechanisms. American Journal of Clinical Nutrition 79(6): 935-945.

Lavie, C. J., R. V. Milani, et al. (2009). Omega-3 Polyunsaturated Fatty Acids and Cardiovascular Diseases. J Am Coll Cardiol 54(7): 585-594.

Leahy, K. M., R. L. Ornberg, et al. (2002). Cyclooxygenase-2 Inhibition by Celecoxib Reduces Proliferation and Induces Apoptosis in Angiogenic Endothelial Cells in Vivo. Cancer Research 62(3): 625-631.

Lee, J. Y. and D. H. Hwang (2002). Docosahexaenoic acid suppresses the activity of peroxisome proliferator-activated receptors in a colon tumor cell line. Biochemical and Biophysical Research Communications 298(5): 667-674.

Lee, T. H., J. M. Menica-Huerta, et al. (1984). Characterization and biologic properties of 5,12-dihydroxy derivatives of eicosapentaenoic acid, including leukotriene B5 and the double lipoxygenase product. Journal of Biological Chemistry 259(4): 2383-2389.

Llor, X., E. Pons, et al. (2003). The effects of fish oil, olive oil, oleic acid and linoleic acid on colorectal neoplastic processes. Clinical Nutrition 22(1): 71-79.

Lund, E. (2006). Dietary fatty acids and colon cancer. Scandinavian Journal of Food and Nutrition 50(S2): 39-44.

Ma, J., E. Giovannucci, et al. (2004). A Prospective Study of Plasma C-Peptide and Colorectal Cancer Risk in Men. Journal of the National Cancer Institute 96(7): 546-553. 
Mangues, R., I. Seidman, et al. (1992). Overexpression of the N-ras proto-oncogene, not somatic mutational activation, associated with malignant tumors in transgenic mice. Oncongene 7(10): 2073-2076.

Martin, C. A., V. V. d. Almeida, et al. (2006). Ácidos graxos poliinsaturados ômega-3 e ômega-6: importância e ocorrência em alimentos. Revista de Nutrição 19: 761-770.

Moreira, A. P. B., C. M. Sabarense, et al. (2009). Fish oil ingestion reduces the number of aberrant crypt foci and adenoma in 1,2-dimethylhydrazine-induced colon cancer in rats. Brazilian Journal of Medical and Biological Research 42: 1167-1172.

Murff, H. J., X.-O. Shu, et al. (2009). A Prospective Study of Dietary Polyunsaturated Fatty Acids and Colorectal Cancer Risk in Chinese Women. Cancer Epidemiology Biomarkers \& Prevention 18(8): 2283-2291.

Murphy, G., S. Devesa, et al. (2011). Sex disparities in colorectal cancer incidence by anatomic subsite, race and age. Int. J. Cancer 128(1668-1675).

Narayanan, B. A., N. K. Narayanan, et al. (2003). Modulation of Inducible Nitric Oxide Synthase and Related Proinflammatory Genes by the Omega-3 Fatty Acid Docosahexaenoic Acid in Human Colon Cancer Cells. Cancer Research 63(5): 972-979.

Nkondjock, A., B. Shatenstein, et al. (2003). Assessment of risk associated with specific fatty acids and colorectal cancer among French-Canadians in Montreal: a case-control study. International Journal of Epidemiology 32(2): 200-209.

Nowak, J., K. H. Weylandt, et al. (2007). Colitis-associated colon tumorigenesis is suppressed in transgenic mice rich in endogenous n-3 fatty acids. Carcinogenesis 28(9): 1991-1995.

Oh, K., W. C. Willett, et al. (2005). Dietary Marine n-3 Fatty Acids in Relation to Risk of Distal Colorectal Adenoma in Women. Cancer Epidemiology Biomarkers \& Prevention 14(4): 835-841.

Pai, R., T. Nakamura, et al. (2003). Prostaglandins promote colon cancer cell invasion; signaling by cross-talk between two distinct growth factor receptors. The FASEB Journal 17(12): 1640-1647.

Rao, C. V. and B. S. Reddy (1993). Modulating effect of amount and types of dietary fat on ornithine decarboxylase, tyrosine protein kinase and prostaglandins production during colon carcinogenesis in male F344 rats. Carcinogenesis 14(7): 1327-1333.

Ravasco, P., M. M. Aranha, et al. (2009). Colorectal cancer: Can nutrients modulate NF[kappa]B and apoptosis? Clinical Nutrition.

Rosa, D. D., R. L. Sales, et al. (2010). Flaxseed, olive and fish oil influence plasmatic lipids, lymphocyte migration and morphometry of the intestinal of Wistar rats. Acta Cirúrgica Brasileira 25(3).

Rose, D. P. and J. M. Connolly (1999). Omega-3 fatty acids as cancer chemopreventive agents. Pharmacology \& Therapeutics 83(3): 217-244.

Roynette, C. E., P. C. Calder, et al. (2004). n-3 Polyunsaturated fatty acids and colon cancer prevention. Clinical Nutrition 23(2): 139-151.

Russo, G. L. (2009). Dietary n - 6 and $n-3$ polyunsaturated fatty acids: From biochemistry to clinical implications in cardiovascular prevention. Biochemical Pharmacology 77(6): 937-946. 
Shao, J., H. Sheng, et al. (1999). Coordinate regulation of cyclooxygenase-2 and TGF- $\beta 1$ in replication error-positive colon cancer and azoxymethane-induced rat colonic tumors. Carcinogenesis 20(2): 185-191.

Shigesawa, A., N. Onoda, et al. (1998). Elevation in putrescine level and spermidine/spermine N1-acetyltransferase activity coincide with tumor development in 1,2-dimethylhydrazine-induced rat colon. Oncol Rep. 5(1): 125-129.

Simopoulos, A. (2002). The importance of the ratio of omega-6/omega-3 essential fatty acids. Biomed Pharmacother 56: 365-379.

Simopoulos, A. (2008). The omega-6/omega-3 fatty acid ratio, genetic variation, and cardiovascular disease. J Clin Nutr 17(1): 131-134.

Singh, J., R. Hamid, et al. (1997). Dietary Fat and Colon Cancer: Modulation of Cyclooxygenase- 2 by Types and Amount of Dietary Fat during the Postinitiation Stage of Colon Carcinogenesis. Cancer Research 57(16): 3465-3470.

Smith, B., G. Holloway, et al. (2010 ). A decreased n-6/n-3 ratio in the fat- 1 mouse is associated with improved glucose tolerance. Appl Physiol Nutr Metab 35(5): 699-706.

Tang, B., E. Böttinger, et al. (1998). Transforming growth factor- $\beta 1$ is a new form of tumor suppressor with true haploid insufficiency. Nat. Med. 4: 802-807.

Terry, P., L. Bergkvist, et al. (2001). No Association between Fat and Fatty Acids Intake and Risk of Colorectal Cancer. Cancer Epidemiology Biomarkers \& Prevention 10(8): 913-914.

Theodoratou, E., G. McNeill, et al. (2007). Dietary Fatty Acids and Colorectal Cancer: A Case-Control Study. American Journal of Epidemiology 166(2): 181-195.

Trevisan, M., J. Liu, et al. (2001). Markers of Insulin Resistance and Colorectal Cancer Mortality. Cancer Epidemiology Biomarkers \& Prevention 10(9): 937-941.

Tuyns, A., M. Haelterman, et al. (1987). Colorectal cancer and the intake of nutrients: oligosaccharides are a risk factor, fats are not. A case-control study in Belgium. Nutr Cancer 10(4): 181-196.

Ursin, V. M. (2003). Modification of Plant Lipids for Human Health: Development of Functional Land-Based Omega-3 Fatty Acids. The Journal of Nutrition 133(12): 4271-4274.

von Schacky, C. and W. S. Harris (2007). Cardiovascular benefits of omega-3 fatty acids. Cardiovascular Research 73(2): 310-315.

Wallace, H. and R. Caslake ( 2001). Polyamines and colon cancer. Eur J Gastroenterol Hepatol. 13(9): 1033-1039.

Wang, D. and R. DuBois (2008). Peroxisome Proliferator-Activated Receptors and progression of colorectal cancer. PPAR Res. 931074.

West, N. J., S. K. Clark, et al. (2010). Eicosapentaenoic acid reduces rectal polyp number and size in familial adenomatous polyposis. Gut 59(7): 918-925.

Whelan, J. and M. F. McEntee (2004). Dietary (n-6) PUFA and Intestinal Tumorigenesis. The Journal of Nutrition 134(12): 3421S-3426S.

Wijendran, V. and K. C. Hayes (2004). Dietary n-6 and n-3 Fatty Acid Balance and Cardiovascular Health. Annual Review of Nutrition 24(1): 597-615.

Willett, W. C. (1998). Dietary fat intake and cancer risk: a controversial and instructive story. Seminars in Cancer Biology 8(4): 245-253.

Willett, W. C. (2001). Diet and Cancer: One View at the Start of the Millennium. Cancer Epidemiology Biomarkers \& Prevention 10(1): 3-8. 
Wortman, P., Y. Miyazaki, et al. (2009). n3 and n6 polyunsaturated fatty acids differentially modulate prostaglandin E secretion but not markers of lipogenesis in adipocytes. Nutrition $\mathcal{E}$ Metabolism 6(1): 5.

$\mathrm{Xu}, \mathrm{L} ., \mathrm{C}$. Han, et al. (2006). Cross-talk between Peroxisome Proliferator-Activated Receptor $\delta$ and Cytosolic Phospholipase A2 $\alpha$ /Cyclooxygenase-2/Prostaglandin E2 Signaling Pathways in Human Hepatocellular Carcinoma Cells. Cancer Research 66(24): 1185911868.

Zha, S., V. Yegnasubramanian, et al. (2004). Cyclooxygenases in cancer: progress and perspective. Cancer Letters 215(1): 1-20. 


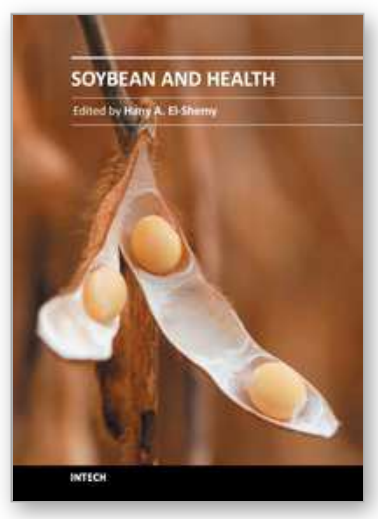

\author{
Soybean and Health \\ Edited by Prof. Hany El-Shemy
}

ISBN 978-953-307-535-8

Hard cover, 502 pages

Publisher InTech

Published online 12, September, 2011

Published in print edition September, 2011

Worldwide, soybean seed proteins represent a major source of amino acids for human and animal nutrition. Soybean seeds are an important and economical source of protein in the diet of many developed and developing countries. Soy is a complete protein, and soy-foods are rich in vitamins and minerals. Soybean protein provides all the essential amino acids in the amounts needed for human health. Recent research suggests that soy may also lower risk of prostate, colon and breast cancers as well as osteoporosis and other bone health problems, and alleviate hot flashes associated with menopause. This volume is expected to be useful for student, researchers and public who are interested in soybean.

\title{
How to reference
}

In order to correctly reference this scholarly work, feel free to copy and paste the following:

Tatiana Fiche Salles Teixeira, Ana Paula Boroni Moreira, Damiana Diniz Rosa and Maria do Carmo Gouveia Peluzio (2011). Soybean Oil: How Good or How Bad in Comparison with Other Dietary Oils in the Context of Colon Cancer, Soybean and Health, Prof. Hany El-Shemy (Ed.), ISBN: 978-953-307-535-8, InTech, Available from: http://www.intechopen.com/books/soybean-and-health/soybean-oil-how-good-or-how-bad-incomparison-with-other-dietary-oils-in-the-context-of-colon-cancer

\section{INTECH}

open science | open minds

\section{InTech Europe}

University Campus STeP Ri

Slavka Krautzeka 83/A

51000 Rijeka, Croatia

Phone: +385 (51) 770447

Fax: +385 (51) 686166

www.intechopen.com

\section{InTech China}

Unit 405, Office Block, Hotel Equatorial Shanghai

No.65, Yan An Road (West), Shanghai, 200040, China 中国上海市延安西路65号上海国际贵都大饭店办公楼 405 单元

Phone: +86-21-62489820

Fax: $+86-21-62489821$ 
(C) 2011 The Author(s). Licensee IntechOpen. This chapter is distributed under the terms of the Creative Commons Attribution-NonCommercialShareAlike-3.0 License, which permits use, distribution and reproduction for non-commercial purposes, provided the original is properly cited and derivative works building on this content are distributed under the same license. 